\title{
Plasma concentrations of nociceptin/orphanin FQ: comparison of levels after general and neuraxial anesthesia for arthroscopic knee surgery
}

\author{
Heeseung Lee and Heehun Jeon \\ Department of Anesthesiology and Pain Medicine, School of Medicine, Ewha Womans University, Seoul, Korea
}

Background: Nociceptin/orphanin FQ (N/OFQ) is an endogenous opioid heptadecapeptide. Preclinically, the pharmacologic action of N/OFQ has been characterized for the treatment of pain in non-human primates. Clinically, the pharmacologic action of N/OFQ is unclear, and concentrations have only been measured under certain clinical conditions. The aims of this study were to measure the plasma concentrations of N/OFQ in different postoperative pain states and to identify the potential relationship between postoperative pain states and N/OFQ plasma concentrations.

Methods: Two groups of 14 patients scheduled for knee arthroscopy were included in this study. Postoperative pain in the first group (IV group) was controlled by intravenous patient-controlled analgesia (IV-PCA). Postoperative pain in the second group (ES group) was controlled by epidural patient-controlled analgesia (E-PCA) or the remnant analgesic effects of spinal anesthesia. Plasma concentrations of N/OFQ were measured by enzyme-linked immunosorbent assay. Numerical rating scale (NRS) scores were recorded for all patients. Differences between the two groups with regards to plasma concentrations of N/OFQ and NRS scores were evaluated by the Mann-Whitney $U$-test.

Results: Plasma concentrations of N/OFQ (mean \pm SD) were $70.4 \pm 128.0 \mathrm{pg} / \mathrm{ml}$ in the IV group and $19.2 \pm 43.4 \mathrm{pg} / \mathrm{ml}$ in the ES group. NRS scores (mean \pm SD) were $3.1 \pm 1.9$ in the IV group and $0.5 \pm 1.1$ in the ES group. The differences in plasma N/OFQ concentrations between groups were not significant $(\mathrm{P}=0.06)$. NRS scores were significantly lower in the ES group as compared with the IV group $(\mathrm{P}=0.0019)$.

Conclusions: Plasma concentrations of N/OFQ increase in acute postoperative pain states, but are not correlated with the level of postoperative pain. (Korean J Anesthesiol 2013; 65: 327-330)

Key Words: Orphanin FQ, Postoperative pain, Nociceptin.

\footnotetext{
Received: February 15, 2013. Revised: 1st, April 3, 2013; 2nd, April 9, 2013. Accepted: April 25, 2013.

Corresponding author: Heeseung Lee, M.D., Ph.D., Department of Anesthesiology and Pain Medicine, School of Medicine, Ewha Womans University, Ewha Womans University Mokdong Hospital, 911-1, Mok 5-dong, Yangcheon-gu, Seoul 158-710, Korea. Tel: 82-2-2650-2670, Fax: 822-2655-2924, E-mail: leehee@ewha.ac.kr

(c) This is an open-access article distributed under the terms of the Creative Commons Attribution Non-Commercial License (http:// creativecommons.org/licenses/by-nc/3.0/), which permits unrestricted non-commercial use, distribution, and reproduction in any medium, provided the original work is properly cited.
} 


\section{Introduction}

Nociceptin/orphanin FQ (N/OFQ) is an endogenous opioid peptide discovered almost 15 years ago. The N/OFQ receptor (nociceptin opioid peptide, NOP) shares 60\% amino acid homology with other opioid receptors, especially kappa opioid peptide (KOP) receptors [1]. Despite the sequence homology between the N/OFQ receptor and other opioid receptors, the N/ OFQ receptor does not share affinity profiles with other opioid receptors and is highly selective for NOP [2]. NOP receptors have a ubiquitous distribution throughout the central and peripheral nervous systems [3].

Insights into N/OFQ and the NOP receptor have been gained using the tools of molecular biology, and the functional activity of N/OFQ has been examined by in vivo investigations. In rodents, N/OFQ acts as a nociceptive supraspinally [4], but as an analgesic or anti-hyperalgesic intrathecally and peripherally [5-7]. In non-human primates, nociceptin acts as an analgesic regardless of its route of administration [8-10]. However, the in vivo function of nociceptin and the NOP receptor system is less clear. The N/OFQ-NOP receptor system may participate in both the development of acute inflammatory pain and the modulation of chronic neuropathic pain.

Our clinical understanding of N/OFQ is limited. Some injectable NOP ligands have shown systemic analgesic effects in nonhuman primates [11]. Significant variations in the levels of N/OFQ have been reported in plasma [12] or cerebrospinal fluid (CSF) in different pain states [13]. We focused on changes in plasma N/OFQ levels in different postoperative pain states to determine if more severe pain increased the production of N/OFQ.

\section{Materials and Methods}

A total of 28 patients scheduled for elective knee arthroscopy were enrolled in this study. All patients were between 18-55 years old, American Society of Anesthesiologists Physical status I or II, and had no previous history of drug or alcohol addiction. After obtaining Institutional Review Board approval and written informed consent, patients were randomly divided into two groups. In one group (IV group), analgesia was achieved using intravenous patient-controlled analgesia (IV-PCA) after the operation. IV-PCA parameters included an hourly basal rate of $5.42 \mu \mathrm{g}$ fentanyl and $1.25 \mathrm{mg}$ ketorolac with the same doses of both drugs administered as a bolus when the patient pressed the PCA control button. Maximum hourly doses of fentanyl and ketorolac were set at $22 \mu \mathrm{g}$ and $5 \mathrm{mg}$, respectively. In this group, general anesthesia was induced with thiopental sodium $(250 \mathrm{mg}$ $i v$ ), midazolam ( $5 \mathrm{mg} i v)$, fentanyl $(1 \mu \mathrm{g} / \mathrm{kg} i v)$, and rocuronium $(0.6 \mathrm{mg} / \mathrm{kg}$ iv. $)$, and maintained with $\mathrm{O}_{2}-\mathrm{N}_{2} \mathrm{O}(1.5 \mathrm{~L}-1.5 \mathrm{~L})$ with 1.5-2 \%vol sevoflurane. In the ES group, analgesia was achieved with either epidural patient-controlled analgesia (E-PCA) or the post-operative remnant effects of spinal anesthesia. The target spinal level of the neuraxial block was T10 for the operation. Approximately $10-12 \mathrm{mg}$ of $0.5 \%$ bupivacaine was used for spinal anesthesia in the ES group in either combined spinalepidural anesthesia or spinal anesthesia alone. In the postoperative anesthesia care unit (PACU), blood was sampled within 10 min of arrival to the unit to measure N/OFQ plasma concentrations. The sampled blood was immediately centrifuged $\left(4^{\circ} \mathrm{C}\right.$, $30 \mathrm{~min}, 20000 \mathrm{rpm}$ ), and aspirated supernatants were frozen at $70^{\circ} \mathrm{C}$. Plasma concentrations of N/OFQ were measured for each patient with commercially available enzyme-linked immunosorbent assay (ELISA) kits (Green Cross Reference Lab., Yongin, Korea). Numerical rating scale (NRS) scores were also recorded simultaneously.

The number of subjects included in each group was based on the previous reports of Ko and colleagues [12]. According to Ko et al., we assumed the SD of plasma nociceptin levels of the two groups to be 9 . The sample size was designed to demonstrate a difference of 10 between the two groups. In the power calculations, 0.05 was used as the criterion for statistical significance (alpha), and a power level of $80 \%$ with a two-tailed t-test was deemed sufficient. All measurements are expressed as means and SD. An unpaired t-test was used to compare demographic data between the two groups because they followed a normal distribution, and the Mann-Whitney $U$-test was performed to compare plasma levels of nociceptin and NRS scores between the two groups because they did not follow a normal distribution. All statistical calculations were made using GraphPad Prism (Prism version 6.0, GraphPad Software, Inc., San Diego, CA, USA). P values below 0.05 were considered statistically significant.

\section{Results}

There were no significant differences in age, height, weight, or operating time between the two groups (Table 1). Plasma

Table 1. Demographic Data

\begin{tabular}{lcc}
\hline & Group IV & Group ES \\
\hline M/F & $6 / 8$ & $8 / 6$ \\
Age $(\mathrm{yr})$ & $42.8 \pm 10.9$ & $42.6 \pm 13.5$ \\
Height $(\mathrm{cm})$ & $167.4 \pm 8.1$ & $171.8 \pm 4.9$ \\
Weight $(\mathrm{kg})$ & $72.6 \pm 9.1$ & $73.1 \pm 8.5$ \\
Operating time (min) & $126.1 \pm 87.6$ & $125.4 \pm 89.1$ \\
\hline
\end{tabular}

All parameters except the number of males/females are expressed as means \pm SD. There were no significant differences in demographic variables between the two groups. IV Group: intravenous patient-controlled analgesia, ES Group: either epidural patient-controlled analgesia or remnant analgesic effects of spinal anesthesia. 


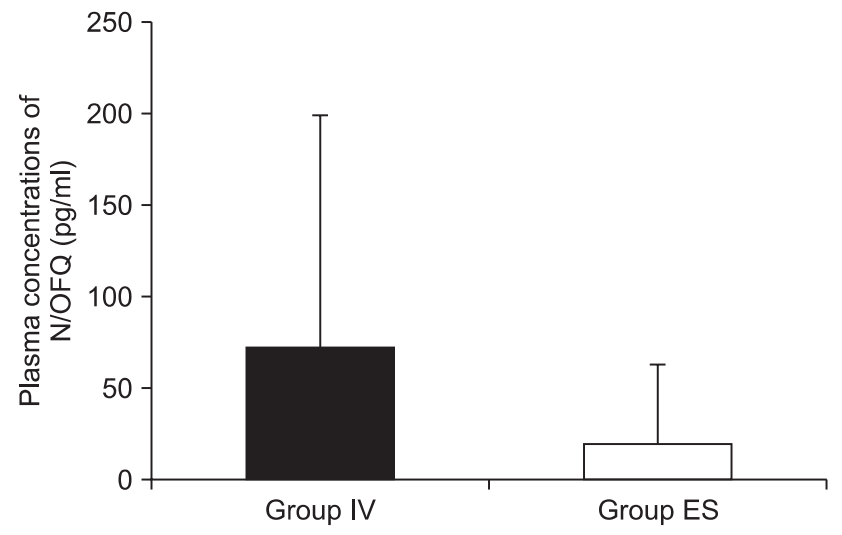

Fig. 1. Plasma concentrations of nociceptin/orphanin FQ (N/OFQ). IV Group $(\mathrm{n}=14)$ : intravenous patient-controlled analgesia, ES Group $(\mathrm{n}=$ 14): either epidural patient-controlled analgesia or the analgesic effects of spinal anesthesia after operation. There was no significant difference between the two groups in terms of plasma N/OFQ concentrations $(\mathrm{P}=$ 0.06 ) according to the Mann-Whitney U-test.

concentrations of N/OFQ (mean \pm SD) were $70.4 \pm 128.0 \mathrm{pg} / \mathrm{ml}$ in the IV group and $19.2 \pm 43.4 \mathrm{pg} / \mathrm{ml}$ in the ES group (Fig. 1). The median (interquartile ranges) plasma concentration values of N/OFQ were $31.5(0-77.8)$ in the IV group and $1.0(0-20.0)$ in the ES group. N/OFQ was identified in all plasma samples, and there was marked inter-patient variation but no significant intra-patient variation in duplicate values. There were no significant differences between the two groups in plasma N/OFQ concentrations $(\mathrm{P}=0.06)$. NRS scores (mean $\pm \mathrm{SD})$ were $3.1 \pm 1.9$ in the IV group and $0.5 \pm 1.1$ in the ES group (Fig. 2). The median (interquartile ranges) NRS scores were $3.0(2.3-5.0)$ in the IV group and $0(0-0.3)$ in the ES group. NRS scores were significantly lower in the ES group than in the IV group $(\mathrm{P}=0.0019)$.

\section{Discussion}

For the first time, we measured plasma concentrations of N/ OFQ in different postoperative pain states and found that the mean level was $70.4 \pm 128.0 \mathrm{pg} / \mathrm{ml}$ in the IV group and $19.2 \pm$ $43.4 \mathrm{pg} / \mathrm{ml}$ in the ES group. A previous study reported N/OFQ levels as being approximately $10 \mathrm{pg} / \mathrm{ml}$ in healthy volunteers [12]. Even in the setting of acute pain, the plasma concentration of N/OFQ has been reported to be approximately $20 \mathrm{pg} / \mathrm{ml}[12,13]$. The N/OFQ concentration in cerebrospinal fluid has been reported to be between $60-70 \mathrm{pg} / \mathrm{ml}$ [14], which is much higher than the plasma concentration of N/OFQ. Compared with values reported in previous literature, we measured much higher concentrations of plasma N/OFQ in the immediate postoperative period.

We hypothesized that N/OFQ may be produced in response to painful surgical stimulation and physical stress. Release of endogeneous N/OFQ from the spinal dorsal horn may modulate systemic and intrathecal pain processing. In the IV group,

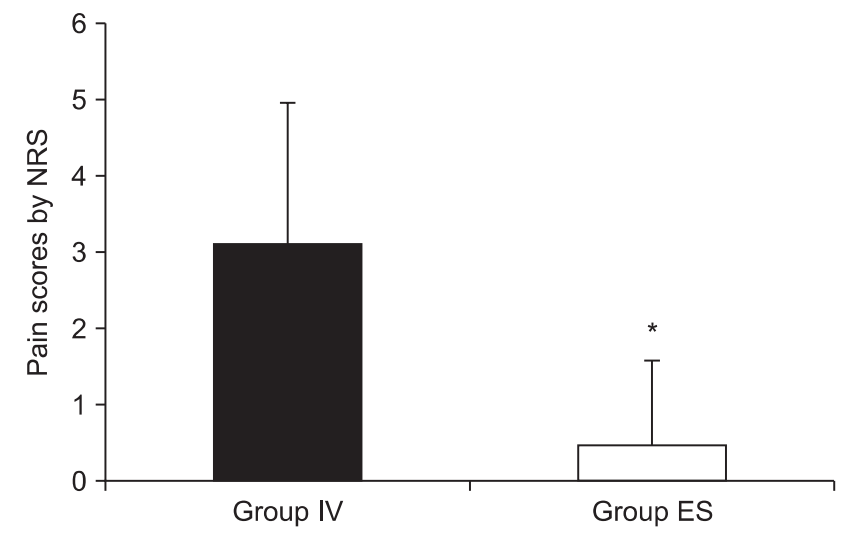

Fig. 2. Pain scores by numerical rating scale (NRS). IV Group $(\mathrm{n}=14)$ : intravenous patient-controlled analgesia, ES Group ( $n=14)$ : either epidural patient-controlled analgesia or the analgesic effects of spinal anesthesia. NRS scores were significantly lower in the ES group as compared with the IV group $(* \mathrm{P}=0.0019)$ according to the MannWhitney U-test.

general anesthesia was performed, and patients in the PACU were not influenced by preemptive analgesia as were patients in the ES group. In the ES group, patients were almost physically stress-free at the beginning of the procedure. Therefore, higher levels of N/OFQ may have been released and entered systemic circulation in the IV group as compared with the ES group, resulting in increased N/OFQ plasma concentrations. The mean NRS score was significantly lower in the ES group than in the IV group, at $3.1 \pm 1.9$ versus $0.5 \pm 1.1$, respectively. This indicates that the ES group experienced less overall post-operative pain than the IV group. These results suggest that painful physical stress can immediately provoke an increase in the plasma concentration of N/OFQ. The difference in plasma N/OFQ levels was not statistically different between groups $(\mathrm{P}=0.06$ ), which was consistent with the findings of Brooks et al. [13] that acute labor pain did not influence the concentration of N/OFQ in the plasma or cerebrospinal fluid.

Many researchers have been interested in the relationship between N/OFQ levels and pain intensity. Some researchers have postulated that endogeneous N/OFQ might be increased in chronic pain patients. Ko et al. [12] reported that plasma levels of N/OFQ were significantly elevated in acute, subacute, and chronic pain subjects compared with normal controls, but they were unable to identify serial inter-group differences in terms of pain duration except in acute vs. chronic pain subjects. Baraniuk et al. [15] evaluated N/OFQ CSF levels in fibromyalsia and chronic low back pain patients. They reported that even though CSF levels of met-enkephalin- $\mathrm{Arg}^{6}-\mathrm{Phe}^{7}$ were inversely correlated with systemic pain threshold, CSF levels of N/OFQ were not significantly correlated with a specific pain threshold. Other researchers demonstrated that exogeneous synthetic N/ OFQ had analgesic potency in non-human primates. Ko et al. 
reported that the synthetic N/OFQ agonists Ro 64-6198 [8] and UFP-112 [10] clearly showed analgesic potency as powerful as that of $\mu$-opioid agonist and additionally demonstrated receptor selectivity.

Although the normal plasma concentrations of N/OFQ reported in previous studies are comparable to our data, the limitations of this study should not be ignored, and include a lack of preoperative N/OFQ plasma level measurements and measurements of N/OFQ concentrations in the CSF. Furthermore, we still cannot clarify the mechanisms of N/OFQ-induced pain modulation using this study design. Even though our data do not support the hypothesis that postoperative pain has an immediate influence on the plasma concentration of N/OFQ, further in vivo preclinical research is required to confirm our findings, and it is important to perform more studies to increase our understanding of pain modulation treatment [15].

In conclusion, we found that although plasma concentrations of N/OFQ were not significantly higher in the group with the higher NRS scores, we can conclude that acute postoperative pain is nevertheless a powerful inducer of N/OFQ production in a clinical setting compared with previously reported, normal plasma concentrations of N/OFQ.

\section{References}

1. Meunier JC, Mollereau C, Toll L, Suaudeau C, Moisand C, Alvinerie P, et al. Isolation and structure of the endogenous agonist of opioid receptor-like ORL1 receptor. Nature 1995; 377: 532-5.

2. Calo' G, Bigoni R, Rizzi A, Guerrini R, Salvadori S, Regoli D. Nociceptin/orphanin FQ receptor ligands. Peptides 2000; 21 : 935-47.

3. Mollereau C, Simons MJ, Soularue P, Liners F, Vassart G, Meunier JC, et al. Structure, tissue distribution, and chromosomal localization of the prepronociceptin gene. Proc Natl Acad Sci USA 1996; 93: 8666-70.

4. Rizzi A, Bigoni R, Marzola G, Guerrini R, Salvadori S, Regoli D, et al. The nociceptin/orphanin FQ receptor antagonist, [Nphe1]NC(1-13) $\mathrm{NH} 2$, potentiates morphine analgesia. Neuroreport 2000; 11: 2369-72.

5. Obara I, Przewlocki R, Przewlocka B. Spinal and local peripheral antiallodynic activity of Ro64-6198 in neuropathic pain in the rat. Pain 2005; 116: 17-25.

6. Agostini S, Eutamene H, Broccardo M, Improta G, Petrella C, Theodorou V, et al. Peripheral anti-nociceptive effect of nociceptin/orphanin FQ in inflammation and stress-induced colonic hyperalgesia in rats. Pain 2009; 141: 292-9.

7. Ambriz-Tututi M, Rocha-González HI, Castañeda-Corral G, Araiza-Saldaña CI, Caram-Salas NL, Cruz SL, et al. Role of opioid receptors in the reduction of formalin-induced secondary allodynia and hyperalgesia in rats. Eur J Pharmacol 2009; 619: 25-32.

8. Ko MC, Woods JH, Fantegrossi WE, Galuska CM, Wichmann J, Prinssen EP. Behavioral effects of a synthetic agonist selective for nociceptin/orphanin FQ peptide receptors in monkeys. Neuropsychopharmacology 2009; 34: 2088-96.

9. Ko MC, Naughton NN. Antinociceptive effects of nociceptin/orphanin FQ administered intrathecally in monkeys. J Pain 2009; 10: 509-16.

10. Hu E, Calò G, Guerrini R, Ko MC. Long-lasting antinociceptive spinal effects in primates of the novel nociceptin/orphanin FQ receptor agonist UFP-112. Pain 2010; 148: 107-13.

11. Podlesnik CA, Ko MC, Winger G, Wichmann J, Prinssen EP, Woods JH. The effects of nociceptin/orphanin FQ receptor agonist Ro 64-6198 and diazepam on antinociception and remifentanil self-administration in rhesus monkeys. Psychopharmacology (Berl) 2011; 213: 53-60.

12. Ko MH, Kim YH, Woo RS, Kim KW. Quantitative analysis of nociceptin in blood of patients with acute and chronic pain. Neuroreport 2002; 13: 1631-3.

13. Brooks H, Elton CD, Smart D, Rowbotham DJ, McKnight AT, Lambert DG. Identification of nociceptin in human cerebrospinal fluid: comparison of levels in pain and non-pain states. Pain 1998; 78: 71-3.

14. Lambert DG. The nociceptin/orphanin FQ receptor: a target with broad therapeutic potential. Nat Rev Drug Discov 2008; 7: 694-710.

15. Baraniuk JN, Whalen G, Cunningham J, Clauw DJ. Cerebrospinal fluid levels of opioid peptides in fibromyalgia and chronic low back pain. BMC Musculoskelet Disord 2004; 5: 48. 